\title{
Synthesis and Biological Evaluation of Novel $N$-phenyl-5-carboxamidyl Isoxazoles as Potential Chemotherapeutic Agents for Colon Cancer
}

\author{
Jiajiu Shaw ${ }^{1}$, Ben Chen ${ }^{2}$, Jean P. Bourgault ${ }^{3}$, Hao Jiang ${ }^{4}$, Narendra Kumar ${ }^{5}$, Jayshree Mishra ${ }^{5}$, \\ Frederick A. Valeriote ${ }^{6}$, Joe Media ${ }^{6}$, Kevin Bobbitt ${ }^{7}$, Halina Pietraszkiewicz ${ }^{6}$, Matthew Edelstein ${ }^{6}$, \\ Peter R. Andreana ${ }^{3}$
}

${ }^{1} 21^{\text {st }}$ Century Therapeutics, Inc., Ferndale, MI 48220, USA

${ }^{2}$ Department of Internal Medicine, Wayne State University, Detroit, Michigan 48201, USA

${ }^{3}$ Department of Chemistry, Wayne State University, Detroit, Michigan 48202, USA

${ }^{4}$ Department of Neurology, Henry Ford Hospital, Detroit, Michigan 48202, USA

${ }^{5}$ Department of Pharmaceutical Sciences, ILR College of Pharmacy, Texas A\&M University System Health Science Center, Kingsville, Texas 78363, USA

${ }^{6}$ Department of Internal Medicine, Henry Ford Hospital, Detroit, Michigan 48202, USA

${ }^{7}$ Department of Public Health Sciences, Henry Ford Hospital, Detroit, Michigan 48202, USA

Corresponding author:

J Shaw, Ph. D.

$21^{\text {st }}$ Century Therapeutics, Inc.

1366 Hilton Rd. Ferndale

Michigan 48220, USA

Tel: 248-545-0595

E-mail jiajiushaw@gmail.com

Received: 7 September 2011; | Revised: 27 September 2011; | Accepted: 10 October 2011

\section{Abstract}

A new series of isoxazole derivatives, $N$-phenyl-5-carboxamidyl isoxazoles, was investigated for their anticancer activity with solid tumor selectivity. Six $N$-phenyl-5-carboxamidylisoxazoles were chemically synthesized and evaluated by the in vitro disk-diffusion assay and $\mathrm{IC}_{50}$ cytotoxicity determination. The results showed that one of the derivatives, compound 3, $\mathrm{N}$-(4-chlorophenyl)-5-carboxamidyl isoxazole, was the most active against colon 38 and CT-26 mouse colon tumor cells with an $\mathrm{IC}_{50}$ of $2.5 \mu \mathrm{g} / \mathrm{mL}$ for both cell lines. Western blot analysis showed that compound $\mathbf{3}$ significantly down-regulated the expression of phosphorylated-STAT3 in both human and mouse colon cancer cells indicating that the mechanism of action for compound $\mathbf{3}$ may involve the inhibition of JAK3/STAT3 signaling pathways. Flow cytometric analysis with Annexin V staining showed that the death induced by compound $\mathbf{3}$ is mediated through cell necrosis and not apoptotic pathway. In summary, our results show that compound $\mathbf{3}$ is a new $N$-phenyl-5-carboxamidyl isoxazole with potential anticancer activity. Compound $\mathbf{3}$ inhibits the phosphorylation of STAT3, a novel target for chemotherapeutic drugs, and is worthy of further investigation as a potential chemotherapeutic agent for treating colon cancer. 


\section{Introduction}

Isoxazole and some naturally occurring isoxazole derivatives are small molecules with interesting biological activities (Figure 1). For example, ibotenic acid derived from the mushroom Amanita muscaria is a potent neurotoxin [1]. Ibotenic has been shown to be highly neurotoxic when injected directly into the brains of mice and rats [2,3]. It has been reported that ibotenic acid can cross the blood brain barrier unchanged, yet some may be metabolized into another isoxazole derivative, muscimol, in the process (Figure 2) [4, 5]. Muscimol is also produced naturally in the mushrooms Amanita muscaria [3]. It is commonly used in biomedical research as an agonist of $\gamma$-aminobutyric acid $\mathrm{A}$ receptor $\left(\mathrm{GABA}_{\mathrm{A}} \mathrm{R}\right)$. The ligand, $\gamma$-aminobutyric acid $A$ (GABA), is the primary inhibitory neurotransmitter that plays a role in regulating neuronal excitability in the central nervous system [5].

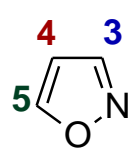

Isoxazole

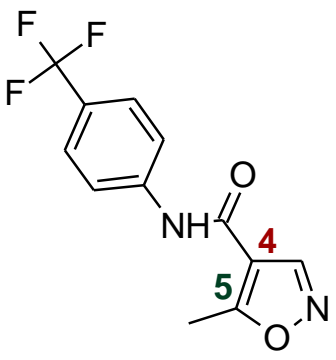

Leflunomide<smiles>NC(C(=O)O)c1cc(O)no1</smiles>

Ibotenic acid

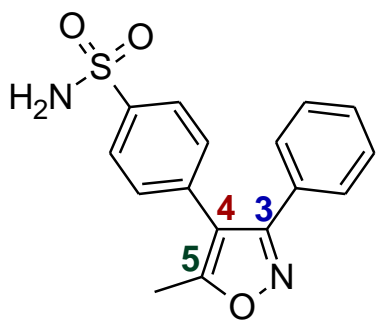

Valdecoxib

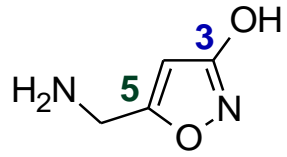

Muscimol

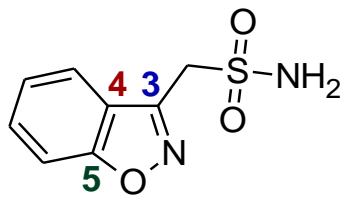

Zonisamide

Figure 1. Structures of isoxazole and some of its derivatives

Isoxazole forms the basis for several drugs such as leflunomide (a disease-modifying antirheumatic drug, DMARD), valdecoxib (a COX-2 inhibitor), and zonisamide (an anticonvulsant) (Figure 1). Two series of isoxazole derivatives ( $N$-phenyl-4-carboxamidyl and $N$ phenyl-3-carboxamidyl isoxazoles) are associated with important biological activities in different therapeutic areas. A well known DMARD, leflunomide, is an $N$-phenyl-4-carboxamidyl isoxazole. The active metabolite of leflunomide, A771726 is known to inhibit TNF- $\alpha$ and IL- $1 \alpha$ from Kupffer cells in vitro [6]. In addition, leflunomide has been shown to inhibit the production of TNF- $\alpha$, IL- $1 \alpha$ and IL-6 induced by bacterial lipopolysaccharides (LPS) in peritoneal macrophages in rats with adjuvant arthritis [7].

Our previous synthetic and biological studies showed that $\mathrm{N}$-(4-chlorophenyl)-3-carboxamidyl5-methylisoxazole is a TNF- $\alpha$ inhibitor [8]. We also showed that a number of $N$-(substitutedphenyl)-3-carboxamidyl-5-methylisoxazoles acted as anti-inflammatory agents in vivo $[9,10]$. Based on the intriguing biological activities of both $\mathrm{N}$ phenyl-4-carboxamidyl and $\mathrm{N}$-phenyl-3carboxamidyl isoxazoles, we hypothesized that the new series of isoxazoles, $N$-phenyl-5carboxamidyl isoxazoles, may possess potent biological activity. As a preliminary investigation for this new series of isoxazoles, we synthesized six $N$-phenyl-5-carboxamidyl isoxazoles (Figure 
2) and investigated these compounds for their anticancer activity using mouse colon carcinoma cells. In addition, a preliminary mechanistic study was carried out in mouse colon 38 cells that constitutively express activated Akt kinase and STAT3 transcriptional factor.

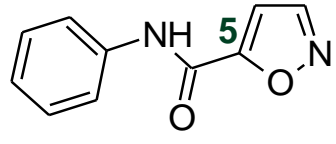

1

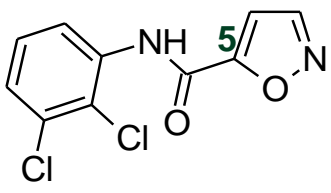

4

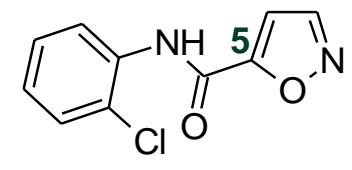

2

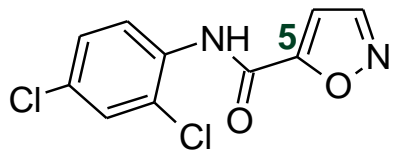

5

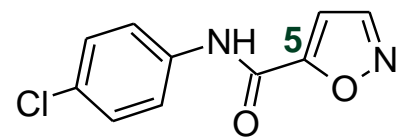

3

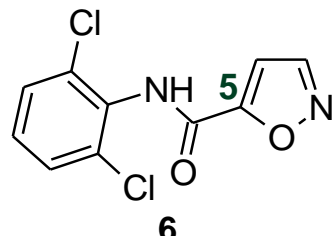

Figure 2. Structures of the six N-phenyl-5-carboxamidylisoxazoles under investigation

\section{Materials and Methods}

\subsection{Chemicals and Materials}

Recombinant Human EGF was purchased from PeproTech (Rocky Hill, NJ). Antibodies against phospho-STAT3 (tyr705), phospho-Akt (ser473) and Akt were obtained from Cell Signaling Technology (Danvers, MA). Antibody against actin was purchased from Santa Cruz Biotechnology (Santa Cruz, CA). Bovine calf serum was purchased from HyClone Laboratories (Logan, UT). Bicinchoninic acid protein (BCA) assay kit and SuperSignal West Pico chemiluminescence substrate system were purchased from Pierce (Rockford, IL). Cocktail protease inhibitors (AEBSF $500 \mu \mathrm{M}$ ) were purchased from EMD4Biosciences (San Diego, CA). All other chemicals used in synthesis and biological studies were purchased from SigmaAldrich (St. Louis, MO) unless otherwise specified.

\subsection{Cell Lines}

The mouse colon 38 tumor cells were maintained in Dulbecco's Modification of Eagle's Medium/Ham's F12, 50/50 Mix (DMEM/F12) (MediaTech, Manassas, VA) containing 2\% bovine calf serum, $2 \mathrm{mM}$ L-glutamine, penicillin $(100 \mathrm{U} / \mathrm{mL})$ and streptomycin $(100 \mu \mathrm{g} / \mathrm{mL}), 10$ $\mathrm{ng} / \mathrm{mL}$ recombinant human-EGF, $1 \%$ insulintransferrin-selenium-A (ITS-A) solution
(Invitrogen, Carlsbad, $\mathrm{CA}$ ) at $37^{\circ} \mathrm{C}$ and $5 \% \mathrm{CO}_{2}$ CT-26 mouse and Caco-2 human colon carcinoma cells were maintained in RPMI 1640 DMEM medium (MediaTech, Manassas, VA) containing $10 \%$ bovine calf serum, $1 \mathrm{mM}$ sodium pyruvate, $10 \mathrm{mM}$ HEPES, $2 \mathrm{mM}$ glutamine, penicillin (100 $\mathrm{U} / \mathrm{mL})$ and streptomycin $(100 \mu \mathrm{g} / \mathrm{mL})$, and $2 \%$ of $7.5 \%$ w/v $\mathrm{NaHCO}_{3}$ solution. Mouse L1210 leukemia cells were maintained in RPMI-1640 medium containing $15 \%$ bovine calf serum, $2 \mathrm{mM}$ glutamine and 1\% MEM amino acids (MediaTech, Manassas, VA).

\subsection{Mouse Bone Marrow Cells}

Mouse bone marrow cells were obtained from female C57BL/6 mice (Jackson Laboratories, Bar Harbor, Maine) by flushing the femurs with $3 \mathrm{~mL}$ of cold medium using a G25 needle. Single cell suspension was prepared by passing the cells through a G18 needle five times to disperse cell cluster and aggregates. The cell mixture was then centrifuged at $300 \times \mathrm{g}$ (Thermo Electron IEC CL31 centrifuge) for $5 \mathrm{~min}$. The medium was decanted and the cells were suspended in $5 \mathrm{~mL}$ of fresh media for counting.

\subsection{Synthesis of Compounds 1 - 6}

A schematic representation for the synthesis of compounds $\mathbf{1}-\mathbf{6}$ is shown in Figure 3.

The general procedure for synthesizing these compounds is described as follows: To a dry 10 
$\mathrm{mL}$ vial with a stir bar, the appropriate aniline, $(1.52 \mathrm{mmol})$ and triethylamine $(1.67 \mathrm{mmol})$ were added. The vial was then flushed with argon and capped. Under argon, $2.5 \mathrm{~mL}$ of dry dichloromethane was then added to the vial. Finally, the acid chloride $(1.52 \mathrm{mmol})$ was added slowly to the vial and the reaction was allowed to stir for 3 hours. The reaction was then quenched with $3 \mathrm{~mL}$ of $5 \% \mathrm{HCl}$ and washed consecutively with saturated $\mathrm{NaHCO}_{3}$ solution, followed by brine. The organic and aqueous layers were then
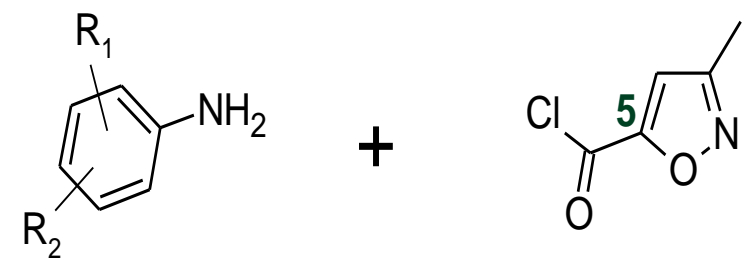

separated and the aqueous layer was extracted three times using $5 \mathrm{~mL}$ of dichloromethane. The combined organic layers were dried over $\mathrm{MgSO}_{4}$, filtered, concentrated, and purified by recrystallization using methanol and two drops of water (three times). Excess triethylamine was removed under vacuum. Compounds $\mathbf{1}$ - 5 were successfully crystallized using the method described above. Compound $\mathbf{6}$ was purified using flash column chromatography with normal phase silica gel (ethyl acetate:hexane, 1:1 v/v).

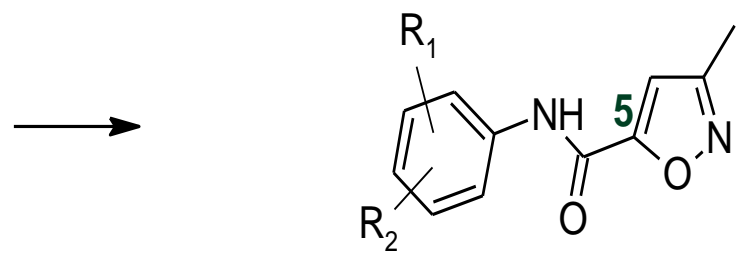

Figure 3. Synthetic scheme of the proposed compounds, wherein $\mathrm{R}_{1}=\mathrm{Cl}$ and $\mathrm{R}_{2}=\mathrm{H}$ or $\mathrm{Cl}$

\subsection{Disk Diffusion Soft-Agar Colony Formation Assay for Cytotoxicity}

A disk diffusion assay was used as a screening tool to select a compound's activity against solid tumors in vitro [11]. Two murine neoplasms, colon 38 and L1210 leukemia along with one normal cell type (bone marrow hematopoietic progenitor) were utilized. In a typical assay, $30 \mu \mathrm{g}$ of each compound $(15 \mu \mathrm{L}$ of $2 \mathrm{mg} / \mathrm{mL}$ in DMSO) was absorbed on a $6.6 \mathrm{~mm}$ filter disk (Baxter). After air drying in a laminar hood, the disk was placed near the edge of a 60 mm Petri dish containing established tumor cells in a matrix of $0.3 \%$ Noble agar (Sigma Chemical, St. Louis, MO) with suitable medium. After 7 to 10 days (per our standard protocol) of incubation, a zone of inhibition was measured; the diameter of the disk was arbitrarily taken as 200 units and an inhibition zone of 1,000 units was defined as total killing. If a compound showed a zone of $>300$, the compound was considered active and was then examined against mouse L1210 leukemia cell lines for solid tumor selectivity relative to leukemia. If the difference in zone between solid tumor and the leukemia cells was $\geq 250$, the compound was defined as a "hit" (acceptable solid tumor selectivity) and was further examined for potential myelotoxicity using normal mouse bone marrow cells as the source of hematopoietic progenitor cells (CFU-GM assay). For CFU-GM assay, an additional 10\% L-cell conditioned medium was added to culture medium as the source of growth factors for the progenitor cells in vitro [12]. A significant difference in zones between solid tumor cells and normal CFU-GM ( $\geq$ 250) was defined as a potentially favorable therapeutic index (i.e. high ratio of efficacy/toxicity)[13].

\section{6 $\mathrm{IC}_{50}$ Determination}

The $\mathrm{IC}_{50}$ assay was carried out against mouse colon 38 cells and CT-26 colon carcinoma cells. Tumor cells were grown in $5 \mathrm{~mL}$ of suitable culture medium at a starting concentration of $5 \times 10^{4}$ cells per T25 flask. On day 3, cells were exposed to increasing doses of the test compounds $(0-100 \mu \mathrm{g} / \mathrm{mL})$. Flasks were incubated for an additional $120 \mathrm{hr}$ (5 days) in a $5 \% \mathrm{CO}_{2}$ incubator at $37^{\circ} \mathrm{C}$ (per our standard protocol) and the cells were harvested by trypsinization, washed once with HBSS, and re-suspended in an HBSS-trypan blue solution. Both total and viable cells were counted using a hemocytometer. The results were normalized to an untreated control. The $\mathrm{IC}_{50}$ value for viable cells was determined using Prism 4.0. 


\subsection{Western Blot Analysis}

After treatment with different concentration of compound 3 for $24 \mathrm{hr}$, colon 38 , and $\mathrm{Caco}_{2}$ cells were collected and lysed in lysis buffer (20 $\mathrm{mM}$ HEPES, $\mathrm{pH} 7.4,100 \mathrm{mM} \mathrm{NaCl}, 1 \%$ Nonidet $\mathrm{P}-40,0.1 \%$ SDS, $1 \%$ deoxycholic acid, $10 \%$ glycerol, $1 \mathrm{mM}$ EDTA, $1 \mathrm{mM}$ EGTA, $1 \mathrm{mM}$ $\mathrm{NaVO}_{3}, 50 \mathrm{mM} \mathrm{NaF}$, and cocktail protease inhibitors). Soluble proteins were obtained by centrifugation at $12,000 \times \mathbf{g}$ for $10 \mathrm{~min}$ at $4{ }^{\circ} \mathrm{C}$ and protein concentration was measured using a $\mathrm{BCA}$ protein assay kit. Equal amounts of cell lysate were subjected to sodium dodecyl sulfate (SDS)polyacrylamide electrophoresis on Novex trisglycine pre-cast gels (Invitrogen, Carlsbad, CA) and separated proteins were then electrotransferred to PVDF membranes [14, 15]. After incubation with primary antibodies against phospho-STAT3, phospho-Akt, Akt or actin overnight at $4{ }^{\circ} \mathrm{C}$ followed by corresponding secondary antibodies, proteins were visualized using SuperSignal West Pico chemiluminescence substrate system (Pierce, Rockford, IL). The band intensity was analyzed using Scion image software (Scion Corp., Frederick, MD).

\subsection{Flow Cytometric Analysis}

Phosphatidylserine on the plasma membranes of colon 38 cells was stained with Annexin VFITC (eBioscience, San Diego, CA) according to the protocol provided by the manufacturer. Briefly, colon 38 cells $\left(5 \times 10^{5} / \mathrm{mL}\right)$ in T25 flasks ( 5 $\mathrm{mL})$ were treated with increasing concentrations of compound $\mathbf{3}(0,1,5$ and $10 \mu \mathrm{g} / \mathrm{mL}$, respectively) for $24 \mathrm{hrs}$. Thereafter, colon cells were removed from the flask with trypsin, washed with the binding buffer and adjusted to $10 \% \mathrm{~mL}$. Cells $(100 \mu \mathrm{L})$ were stained with $5 \mu \mathrm{L}$ Annexin VFITC in the dark for 15 min. After staining, cells were washed with the binding buffer and resuspended in $200 \mu \mathrm{l}$ binding buffer. Thereafter, $5 \mu \mathrm{l}$ of propidium iodide (PI) $(100 \mu \mathrm{g} / \mathrm{mL})$ was added to each sample and mixed. Flow cytometric analysis was carried out immediately following staining with FACScan (Becton Dickinson), and data analysis was done on PC-LYSYS v1.1. Apoptotic cells were defined as FITC positive and PI negative [16].

\section{Results}

\subsection{Synthesis}

Identification and characterization of compounds $\mathbf{1}$ - $\mathbf{6}$ are summarized in Table 1.

\subsection{Disk Diffusion Assay}

The criteria for (1) solid tumor selectivity relative to leukemia, and (2) in vitro therapeutic index are described in the Materials and Methods (Disk Diffusion Assay). As shown in Table 2, all six compounds showed effective in vitro cytotoxicity against colon 38 cells. Four compounds $(\mathbf{1}, \mathbf{3}, \mathbf{4}$, and 6) demonstrated solid tumor selectivity, but only two compounds (1 and 3) showed acceptable in vitro therapeutic indices $\left({ }_{\mathrm{C} 38} \Delta_{\mathrm{CFU}}>550\right)$.

\subsection{IC $_{50}$ Determination}

$\mathrm{IC}_{50}$ values of the six compound synthesized are shown in Table 3 . Based on the in vitro $\mathrm{IC}_{50}$ values from both colon-38 and CT-26, compound 3 was the most potent with solid tumor selectivity. Among others, compound $\mathbf{3}$ also had the lowest myelotoxicity as determined by bone marrow CFU-GM assay and was selected for further biological and mechanistic studies.

\subsection{Effect of Compound 3 on Akt Kinase and STAT3}

Akt kinase plays an important regulatory role in cell proliferation, growth, and survival. Overexpression and/or activation of Akt kinase are often associated with tumorigenesis and colon cancer progression [17-21]. Since mouse colon 38 cells constitutively express activated Akt kinase, we investigated the effect of compound $\mathbf{3}$ on Akt kinase in colon 38 cells. As shown in Figure 4A, constitutive expression of phosphorylated Akt kinase (p-Akt) was detected in colon 38 cells. More than $50 \%$ of the Akt kinase of colon 38 cells appears to be in phosphorylated states (activated). Treatment of colon 38 cells with compound $\mathbf{3}$ in vitro for $24 \mathrm{hr}$ markedly decreased the levels of phosphorylated Akt kinase in a dose-dependent manner (Figure 4A) with more than two fold decrease in phosphorylation at $10 \mu \mathrm{g} / \mathrm{mL}$. 
Table 1. Identification and characterization data for compound $1-6$

\begin{tabular}{|c|c|}
\hline Compound $\mathbf{1}$ & $\begin{array}{l}\text { Chemical Formula: } \mathrm{C}_{10} \mathrm{H}_{8} \mathrm{~N}_{2} \mathrm{O}_{2} \text {, MW } 188 \\
{ }^{1} \mathrm{H} N \mathrm{NR}\left(400 \mathrm{MHz}, \mathrm{CDCl} l_{3}\right): \mathrm{Ha}, \delta 8.40(\mathrm{~d}, 1 \mathrm{H}, J=2.8 \mathrm{~Hz}) ; \mathrm{Hb}, \delta 7.04(\mathrm{~d}, 1 \mathrm{H}, J=1.6 \\
\mathrm{Hz}) ; \mathrm{Hc}, \delta 8.24(\mathrm{~s}(\mathrm{br}), 1 \mathrm{H}) ; \mathrm{Hd}, \delta 7.66(\mathrm{~d}, 2 \mathrm{H}, J=8.0 \mathrm{~Hz}) ; \mathrm{He}, \delta 7.40(\mathrm{t}, 2 \mathrm{H}, J=7.8 \mathrm{~Hz}) ; \\
\mathrm{Hf}, \delta 7.21(\mathrm{t}, 1 \mathrm{H}, J=7.2 \mathrm{~Hz}) \\
\text { HR-MS: EIMS cald for } \mathrm{C}_{10} \mathrm{H}_{8} \mathrm{~N}_{2} \mathrm{O}_{2}+\mathrm{Na} 211.0483 \text {, found } 211.0478 \\
\text { IR: } 3342,3099,1673,1537,747 \mathrm{~cm}^{-1} \\
\text { Yield: } 78 \%\end{array}$ \\
\hline Con & $\begin{array}{l}\text { Chemical Formula: C10H7N2O2Cl, MW } 222.5 \\
\text { 1H NMR (400 MHz, CDCl3): Ha, } \delta 8.42(\mathrm{~d}, 1 \mathrm{H}, \mathrm{J}=1.6 \mathrm{~Hz}) ; \mathrm{Hb}, \delta 7.06(\mathrm{~d}, 1 \mathrm{H}, \mathrm{J}=1.6 \\
\mathrm{Hz}) ; \mathrm{Hc}, \delta 8.84(\mathrm{~s}(\mathrm{br}), 1 \mathrm{H}) ; \mathrm{HAr}, \delta 8.48(\mathrm{~m}, 1 \mathrm{H}), \delta 7.45(\mathrm{dd}, 1 \mathrm{H}, \mathrm{J}=8.0,1.6 \mathrm{~Hz}), \delta 7.34 \\
(\mathrm{~m}, 1 \mathrm{H}), \delta 7.14(\mathrm{~m}, 1 \mathrm{H}) \\
\text { HR-MS: EIMS cald for C10H7N2O2Cl + Na } 245.0094 \text {, found } 245.0088 \\
\text { IR: } 3404,3314,3106,1705,1674,1530,753 \mathrm{~cm}-1 \\
\text { Yield: } 79 \%\end{array}$ \\
\hline Compound & $\begin{array}{l}\text { Chemical Formula: C10H7N2O2Cl, MW } 222.5 \\
\text { CHN: Cald C H N, found C H N } \\
\text { 1H NMR (400 MHz, CDCl3): Ha, } \delta 8.40(\mathrm{~d}, 1 \mathrm{H}, \mathrm{J}=1.6 \mathrm{~Hz}) ; \mathrm{Hb}, 7.05(\mathrm{~d}, 1 \mathrm{H}, \mathrm{J}=1.6 \mathrm{~Hz}) \text {; } \\
\mathrm{Hc}, 8.31 \text { (s (br), 1H); HAr, } 7.62(\mathrm{~m}, 2 \mathrm{H},), 7.40(\mathrm{~m}, 2 \mathrm{H}, \mathrm{Ar}) \\
\text { 13C NMR (100 MHz, CDCl3): } \delta 151.4,129.4,121.4,107.4 \\
\text { HRMS: EIMS (M+) calcd for C10H7N2O2Cl + Na } 245.0094 \text {, found } 245.0097 \\
\text { IR: } 3323 \mathrm{~cm}-1,3111 \mathrm{~cm}-1,1730 \mathrm{~cm}-1,1664 \mathrm{~cm}-1,1530 \mathrm{~cm}-1,820 \mathrm{~cm}-1 \\
\text { Yield: } 80 \%\end{array}$ \\
\hline Cam & $\begin{array}{l}\text { Chemical Formula: C10H6N2O2Cl2, MW } 257 \\
1 \mathrm{H} \text { NMR }(400 \mathrm{MHz}, \mathrm{CDCl} 3): \mathrm{Ha}, \delta 8.41(\mathrm{~d}, 1 \mathrm{H} \mathrm{J}=2.4) ; \mathrm{Hb}, \delta 7.07(\mathrm{~d}, 1 \mathrm{H}, \mathrm{J}=1.6 \mathrm{~Hz}) ; \\
\mathrm{Hc}, \delta 8.91(\mathrm{~s}(\mathrm{br}), 1 \mathrm{H}) ; \mathrm{HAr}, \delta 8.43(\mathrm{~s}, 1 \mathrm{H}), \delta 8.41(\mathrm{~d}, 1 \mathrm{H}, \mathrm{J}=2.4 \mathrm{~Hz}), \delta 7.28-7.32(\mathrm{~m}, 2 \mathrm{H}) \\
\text { HR-MS: EIMS cald for C10H6N2O2Cl2 + Na } 278.9704 \text {, found } 278.9696 \\
\text { IR: } 3388,3142,1699,1586,1524,774 \mathrm{~cm}-1 \\
\text { Yield: } 79 \%\end{array}$ \\
\hline $\mathrm{H}_{\mathrm{Ar}}$ & $\begin{array}{l}\text { Chemical Formula: C10H6N2O2Cl2, MW } 257 \\
1 \mathrm{H} \mathrm{NMR}(400 \mathrm{MHz}, \mathrm{CDCl} 3) \text { : Ha, } \delta 8.42(\mathrm{~d}, 1 \mathrm{H} \mathrm{J}=1.6 \mathrm{~Hz}) ; \mathrm{Hb}, \delta 7.07(\mathrm{~d}, 1 \mathrm{H}, \mathrm{J}=1.6 \\
\mathrm{Hz}) ; \mathrm{Hc}, \delta 8.78(\mathrm{~s}(\mathrm{br}), 1 \mathrm{H}) ; \mathrm{HAr}, \delta 8.44(\mathrm{~d}, 1 \mathrm{H}, \mathrm{J}=8.8 \mathrm{~Hz}), \delta 7.47(\mathrm{~d}, 1 \mathrm{H}, \mathrm{J}=2.8 \mathrm{~Hz}), \delta \\
7.32(\mathrm{dd}, 1 \mathrm{H}, \mathrm{J}=8.8,2 \mathrm{~Hz}) \\
\text { HR-MS: EIMS cald for C10H6N2O2Cl}+\mathrm{Na} 278.9704 \text {, found } 278.9713\end{array}$ \\
\hline Compound & $\begin{array}{l}\text { Chemical Formula: C10H6N2O2Cl2, MW } 257 \\
\text { 1H NMR ( } 400 \mathrm{MHz}, \mathrm{CDCl} 3) \text { : Ha, } \delta 8.41(\mathrm{~d}, 1 \mathrm{H} \mathrm{J}=1.6 \mathrm{~Hz}) ; \mathrm{Hb}, \delta 7.07(\mathrm{~d}, 1 \mathrm{H}, \mathrm{J}=1.6 \\
\mathrm{Hz}) ; \mathrm{Hc}, \delta 8.17(\mathrm{~s}(\mathrm{br}), 1 \mathrm{H}) ; \mathrm{Hd} \& \mathrm{Hf}, \delta 7.41(\mathrm{~d}, 2 \mathrm{H}, \mathrm{J}=8.0 \mathrm{~Hz}) ; \mathrm{He}, \delta 7.25(\mathrm{t}, 1 \mathrm{H}, \mathrm{J}=8.2 \\
\mathrm{Hz}) \\
\text { HR-MS: EIMS cald for C10H6N2O2Cl2 + Na } 278.9704 \text {, found } 278.9712 \\
\text { IR: } 3257,3030,1684,1511,787 \mathrm{~cm}-1 \\
\text { Yield: } 51 \%\end{array}$ \\
\hline
\end{tabular}


Table 2. Disk diffusion assay results (zone inhibition) of compounds 1 - 6

\begin{tabular}{|c|c|c|c|c|c|c|}
\hline \multirow{2}{*}{ Compound } & \multirow{2}{*}{$\mu \mathrm{g} / \mathrm{disk}$} & \multicolumn{3}{|c|}{ Cells used in Disk-Diffusion Assay } & \multicolumn{2}{|c|}{ Difference in zone units } \\
\hline & & Colon 38 & L1210 & CFU-GM & ${ }_{C 38} \Delta_{L 1210}{ }^{a}$ & ${ }_{\mathrm{C} 38} \Delta_{\mathrm{CFU}}{ }^{\mathrm{b}}$ \\
\hline \multirow[t]{2}{*}{$\mathbf{1}$} & 30 & 1000 & 300 & 550 & 700 & 450 \\
\hline & 7.5 & 500 & 50 & 200 & 450 & 300 \\
\hline 2 & 30 & 350 & 150 & 200 & 200 & 150 \\
\hline \multirow[t]{2}{*}{3} & 7.5 & $>1000$ & 200 & 450 & $>800$ & $>\mathbf{5 5 0}$ \\
\hline & 1.9 & 550 & 50 & 300 & 500 & 250 \\
\hline 4 & 30 & 350 & 100 & 200 & 250 & 150 \\
\hline 5 & 30 & 300 & 100 & 150 & 200 & 150 \\
\hline 6 & 30 & 400 & 150 & 200 & 250 & 150 \\
\hline
\end{tabular}

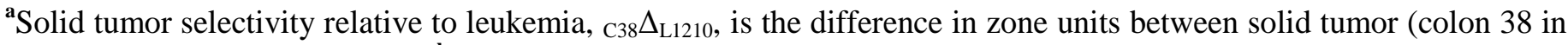
this case) and leukemia L1210. ${ }^{\mathbf{b}}$ In vitro toxicity, ${ }_{\mathrm{C} 38} \Delta_{\mathrm{CFU}}$, is the difference in zone units between solid tumor (colon 38 in this case) and mouse normal bone marrow CFU-GM. ${ }^{c}$ Definition of inhibition zone is described in Materials and Methods.

Table 3. $\mathrm{IC}_{50}$ values $(\mu \mathrm{g} / \mathrm{mL})$ on two colon cancer cell lines

\begin{tabular}{|c|c|c|}
\hline \multirow{2}{*}{ Compound } & \multicolumn{2}{|c|}{ Cell Lines } \\
\cline { 2 - 3 } & Colon 38 & CT-26 \\
\hline 1 & 8.6 & 23 \\
\hline 2 & 32 & $* *$ \\
\hline 3 & $2.5^{*}$ & $2.5^{*}$ \\
\hline 4 & 20 & 26 \\
\hline 5 & 17 & $* *$ \\
\hline 6 & 40 & $* *$ \\
\hline
\end{tabular}

* Meet our criteria of $<5 \mu \mathrm{g} / \mathrm{mL} \quad * *$ Not determined

STAT3 is a down stream transcription factor for JAK-STAT pathways. Both proteins have been shown to be constitutively activated in colorectal cancers [22-24]. Like Akt kinase, STAT3 was also constitutively active in both mouse colon 38 and human colon cancer cells $\mathrm{Caco}_{2}$ as shown by strong signal using phosphorylated STAT3 antibody in control cells (Figure 4B-C). We therefore investigated the effect of compound $\mathbf{3}$ on the activation of STAT3 in colon 38 and Caco-2 cells. Treatment of colon 38 cells with compound 3 for $24 \mathrm{hr}$ significantly down-regulated phosphorylated STAT3 expression in a dosedependent manner. While there was more than four fold decrease in STAT3 tyrosine phosphorylation at $10 \mu \mathrm{g} / \mathrm{mL}$ in colon 38 cells, the decrease in STAT3 phosphorylation was more prominent in human Caco-2 cells where it decreased by more than 10 fold at $80 \mu \mathrm{g} / \mathrm{mL}$. Taken together these results show that compound 3 was a potent STAT3 inhibitor for both mouse and human colon cancer cells.

\subsection{Flow Cytometric Analysis of Apoptotic Cells}

Since both Akt kinase and STAT3 are involved in cell growth and survival, we asked if suppression of Akt and STAT3 in colon 38 cells may trigger an apoptotic response in colon 38 cells. Cells were treated with compounds 3 for 24 hr. Thereafter, cells were removed and subjected to flow cytometric analysis after staining with FITC-annexin V. There was no significant increase of annexin V-binding activity in compound 3-treated colon 38 cells (Data not shown) as compared to control cultures. 
Morphological examination showed that colon 38 cell death appeared to be mediated through necrosis.

\section{Discussion}

In this study, we synthesized and examined six novel $N$-(phenyl)-5-carboxamidylisoxazoles for their anticancer activity in vitro. In a preliminary screening study with the disk-diffusion assay, all six compounds were active against mouse colon38 cells. However, only two of them (compound 1 and 3) showed promising in vitro cytotoxicity and solid tumor selectivity. Judging from the $\mathrm{IC}_{50}$ values $(2.5 \mu \mathrm{g} / \mathrm{mL})$ in subsequent studies, compound $\mathbf{3}$ exerts most potent cytotoxic activity against both colon-38 and CT-26 mouse colon cancer cell lines (Table 3). Furthermore, diskdiffusion assay revealed that compound $\mathbf{3}$ was highly solid-tumor selective as compared to compound 1 (Table 2). Disk-diffusion assay also showed that compound $\mathbf{3}$ exerted a much higher cell killing against tumor cell than normal bone marrow CFU-GM, suggesting that compound $\mathbf{3}$ might have the least myelotoxicity. The molecular scaffold used in this work indicates that the inductive $\mathrm{Cl}$ substitution on the para position of phenyl ring appears to be associated with the best anticancer activity in vitro.

\section{(A)}

$\begin{array}{llll}0 & 1 & 5 & 10 \mu \mathrm{g} / \mathrm{mL} \text { compound } 3\end{array}$
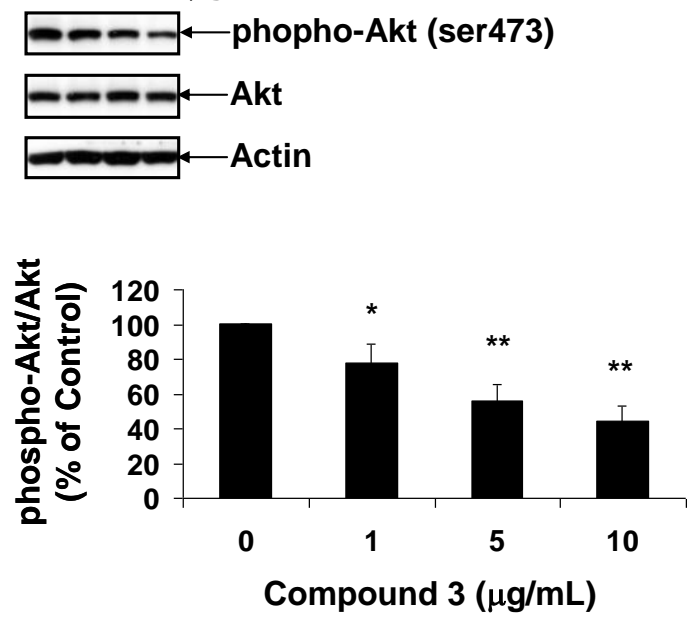

(B)
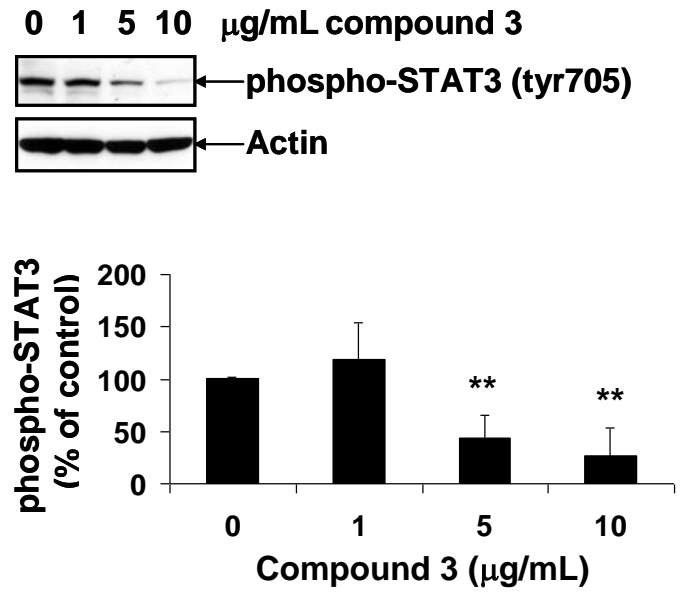

(C)

\section{$\begin{array}{llllll}0 & 40 & 80 & 160 & 200 & \mathrm{mg} / \mathrm{mL} \text { compound } 3\end{array}$}
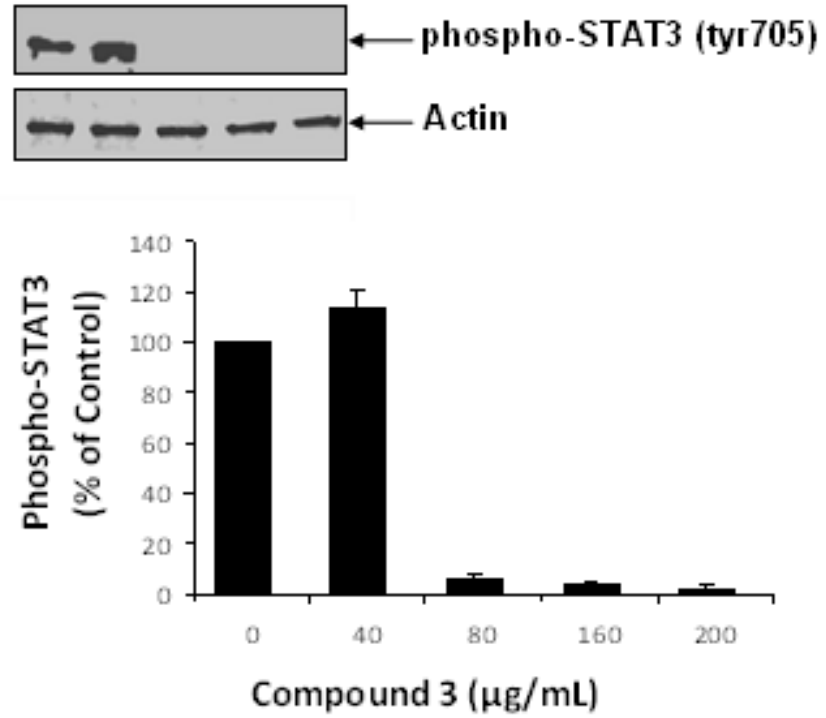

Figure 4. Effect of compound 3 on the activation of Akt and STAT. Colon 38 cells were treated with increasing doses ( 0 to $10 \mu \mathrm{g} / \mathrm{mL}$ ) of compound 3 for 24 hr. Cells were then removed, lysed with lysis buffer. Equal amounts of lysates were subjected to Western blotting using antibodies against phospho-Akt and Akt (A), phosphor-STAT3 and STAT3 (B). Human Caco-2 cells were treated with compound $3(0-200 \mu \mathrm{g} / \mathrm{mL})$ for $24 \mathrm{hr}$ and processed as described in colon 38 cells (C). Antibody against actin was used as "house-keeping protein." Densitometric analysis was performed to measure the band intensity for each blot. Values are means \pm S.D. $* \mathrm{p}<0.05, * * \mathrm{p}<0.005$ vs. medium control, $\mathrm{n}=3$. 
To further analyze the anti-colon cancer activity of compound $\mathbf{3}$, we carried out a series of mechanistic studies on Akt kinase and STAT activities in vitro. Overexpression and/or activation of Akt kinase have been implicated in the tumoregenesis and progression of colorectal cancers [17-21]. As expected, treatment of colon 38 cells in vitro with compound $\mathbf{3}$ markedly deactivated Akt kinase in colon 38 cells as judged by the suppressed levels of phosphorylated Akt kinase (Figure 4A). The inhibition of Akt kinase by compound $\mathbf{3}$ was dose-dependent, with an $\mathrm{IC}_{50}$ of approximately $5 \mu \mathrm{g} / \mathrm{mL}$. This value is very close to and consistent with that obtained by in vitro cytotoxic assay, with an $\mathrm{IC}_{50}$ of $2.5 \mu \mathrm{g} / \mathrm{mL}$ (Table 3). Suppression of cancer cell growth and induction of apoptosis through Akt signaling pathway also have been shown in human colorectal cancer cells $[20,21,25]$. These findings suggest that targeting Akt pathway is of potential in treating patients with colorectal cancers.

STAT3 has been shown to be constitutively activated in some colorectal cancer and is often associated with adverse clinical outcome [22-24, $26,27]$. In recent year, STAT3 has become an attractive therapeutic target for various types of human cancers with constitutively activated STAT3 [23, 28, 29]. STAT3 was constitutively phosphorylated (p-STAT3) in both human and mouse colon cancer cells (Figure 4B-C). Treatment of colon 38 and Caco-2 cells with compound 3 readily suppressed the activation of STAT3 in a dose-dependent manner. The effective concentration for the inhibition of tyrosine phosphorylation of STAT3 was lower for mouse colon cancer cells as compared to human. The differences in the effective concentration could be due to variation in the expression level of STAT3 and associated signaling pathways that lead to STAT3 activation in these models of colorectal cancer.

Both Akt kinase and STAT3 are involved in cell growth and survival and it has been shown that inhibition of Akt and STAT3 can lead to apoptosis activation in various cancer cells [20-23, $27,28,30]$. Induction of apoptosis in colon 38 cells by compound $\mathbf{3}$ was examined by flow cytometric analysis with FITC-annexin V. Unexpectedly, flow cytometric results showed that the cytotoxic effect of compound $\mathbf{3}$ was not mediated through apoptotic pathway. A subsequent study using caspase-3 activation confirmed that compound $\mathbf{3}$ did not induce apoptosis in colon 38 cells (unpublished observation). Judging from morphological changes, cell death appears to be mediated through non-apoptotic necrosis.

Compound 3 induces non-apoptotic cell death through the inhibition of Akt and STAT3 signaling pathways both of which are known to be constitutively activated in various types of colorectal cancer cells. It is not known at present whether compound $\mathbf{3}$ directly interacts with and bind to either Akt or STAT3 at protein level. Compound 3 may inhibit Akt and STAT3 indirectly through other metabolic and signaling pathways. Of relevance to this study, a recent study showed that isoxazole-modified curcumin analog derivatives markedly increased its antitumor activity including against multidrug resistant cells [31]. Still other showed that isoxazole carboxylic acid analogs can act as potent tyrosine phosphatase inhibitors [32]. At present, it is not know whether compound 3 exhibits tyrosine phosphatase inhibitory activity. Additional mechanistic studies including studies with animal tumor modals will be needed to further analyze and establish its therapeutic effect against colon cancers. Taken together, these studies show that isoxazole analogs can form the basis for the development of various therapeutic compounds against cancer and other diseases.

Abbreviations: CFU-GM, colony forming unit for granulocyte and macrophage; DMARD, diseasemodifying anti-rheumatic drug; FITC, fluorescein isothiocyanate; JAK3, Janus kinase $3 ; \mathrm{IC}_{50}$, half maximal inhibitory concentration; PI, propidium iodide; STAT3, signal transducer and activator of transcription 3; TNF- $\alpha$, tumor necrosis factor alpha.

\section{Acknowledgements}

This work was supported by the general fund from $21^{\text {st }}$ Century Therapeutics, Inc. Collaborative efforts from Wayne State University and Henry Ford Health System are acknowledged. This work 
was also supported by Career Development Award from Crohn's \& Colitis Foundation of America (to $\mathrm{NK})$.

\section{References}

1. Gennaro, M.C.; Giacosa, D.; Gioannini, E.; Angelino, S. Hallucinogenic Species in Amanita Muscaria. Determination of Muscimol and Ibotenic Acid by IonInteraction HPLC, J. Liq. Chromatog. Relat. Technol., 1997, 20,413 - 424. DOI: 10.1080/10826079708010660

2. Schwarcz, R.; Hokfelt, T.; Fuxe, K.; Jonsson, G.; Goldstein, M.; Terenius, L. Ibotenic acidinduced neuronal degeneration: a morphological and neurochemical study, Exp. Brain Res., 1979, 37,199-216.

3. Tsunoda, K.; Inoue, N.; Aoyagi, Y.; Sugahara, T. Food hygienic studies of toxigenic basidiomycotina, 1: Simultaneous analysis of ibotenic acid and muscimol in toxic mushroom, Amanita muscaria, and analytical survey on edible mushrooms, J. Food Hyg. Soc. Jpn., 1993, 34,12-17.

4. Michelot, D.; Melendez-Howell, L.M. Amanita muscaria: chemistry, biology, toxicology, and ethnomycology, Mycol. Res., 2003, 107,131-146. DOI: 10.1017/ S0953756203007305

5. Olpe, H.R.; Koella, W.P. The action of muscimol on neurones of the substantia nigra of the rat, Experientia, 1978, 34,235.

6. Yao, H.W.; Li, J.; Chen, J.Q.; Xu, S.Y. A 771726, the active metabolite of leflunomide, inhibits TNF-alpha and IL-1 from Kupffer cells, Inflammation, 2004, 28,97-103. DOI: 10.1023/B:IFLA.0000033025.73363.d3

7. Li, W.D.; Ran, G.X.; Teng, H.L.; Lin, Z.B. Dynamic effects of leflunomide on IL-1, IL-6, and TNF-alpha activity produced from peritoneal macrophages in adjuvant arthritis rats, Acta Pharmacol. Sin., 2002, 23,752-756.

8. Shaw, J.; Liu, C.; Martin, R.; Chen, B.; Holtz, R.; Huang, W.H.; Lee, A.R. Inhibition of tumour necrosis factor-alpha secretion from EpiDermTM tissues by a novel small molecule, UTL-5d, Br. J. Dermatol., 2007,
$157,575-579$. DOI: $10.1111 / \mathrm{j} .1365-2133$. 2007.08025.x

9. Shaw, J.; Chen, B.; Huang, W.H.; Lee, A.R.; Media, J.; Valeriote, F.A. The small-molecule TNF-alpha modulator, UTL-5g, reduces side effects induced by cisplatin and enhances the therapeutic effect of cisplatin in vivo, $J$. Exp.Ther. Oncol., 2011, 9,129-137.

10. Shaw, J.; Chen, B.; Wooley, P.; Huang, W.H.; Lee, A.R.; Zeng, D. Anti-inflammatory and Anti-arthritic Effects of a Novel Leflunomide Analogue, UTL-5b (GBL-5b), American journal of biomedical sciences, 2011, 3,31-39. DOI: 10.5099/aj110100031

11. Valeriote, F.; Grieshaber, C.K.; Media, J.; Pietraszkewicz, H.; Hoffmann, J.; Pan, M.; McLaughlin, S. Discovery and development of anticancer agents from plants, J. Exp. Ther. Oncol., 2002, 2,228-236.

12. Stanley, E.R.; Chen, D.M.; Lin, H.S. Induction of macrophage production and proliferation by a purified colony stimulating factor, Nature, 1978, 274,168-170. DOI: 10.1038/274168a0

13. Nakeff, A.; Valeriote, F.A. Effect of a transplantable leukemia on hematopoietic stem cells in AKR mice, Cancer Treat. Rep., 1978, 62,737-741.

14. Li, X.; Chen, B.D. Histone Deacetylase Inhibitor M344 Inhibits Cell Proliferation and Induces Apoptosis in Human THP-1 Leukemia Cells, Am. J. Biomed. Sci., 2009, 1,352-363. DOI: 10.5099/aj090400352

15. Lin, H.; Subramanian, B.; Nakeff, A.; Chen, B.D. XK469, a novel antitumor agent, inhibits signaling by the MEK/MAPK signaling pathway, Cancer Chemother. Pharmacol., 2002, 49,281-286. DOI: 10.1007/s00280-0020425-7

16. Chen, C.; Lin, H.; Karanes, C.; Pettit, G.R.; Chen, B.D. Human THP-1 monocytic leukemic cells induced to undergo monocytic differentiation by bryostatin 1 are refractory to proteasome inhibitor-induced apoptosis, Cancer Res., 2000, 60,4377-4385.

17. Michl, P.; Downward, J. Mechanisms of disease: PI3K/AKT signaling in gastrointestinal cancers, Z. Gastroenterol., 2005, 43,1133-1139. DOI: 10.1055/s-2005$\underline{858638}$ 
18. Saif, M.W.; Chu, E. Biology of colorectal cancer, Cancer J., 2010, 16,196-201. DOI: 10.1097/PPO.0b013e3181e076af

19. Baba, Y.; Nosho, K.; Shima, K.; Hayashi, M.; Meyerhardt, J.A.; Chan, A.T.; Giovannucci, E.; Fuchs, C.S.; Ogino, S. Phosphorylated AKT expression is associated with PIK3CA mutation, low stage, and favorable outcome in 717 colorectal cancers, Cancer, 2010, 117,1399-1408. DOI: 10.1002/cncr.25630

20. Shin, D.Y.; Lee, W.S.; Lu, J.N.; Kang, M.H.; Ryu, C.H.; Kim, G.Y.; Kang, H.S.; Shin, S.C.; Choi, Y.H. Induction of apoptosis in human colon cancer HCT-116 cells by anthocyanins through suppression of Akt and activation of p38-MAPK, Int. J. Oncol., 2009, 35,14991504. DOI: 10.3892/ijo_00000469

21. Graff, J.R.; McNulty, A.M.; Hanna, K.R.; Konicek, B.W.; Lynch, R.L.; Bailey, S.N.; Banks, C.; Capen, A.; Goode, R.; Lewis, J.E., et al. The protein kinase Cbeta-selective inhibitor, Enzastaurin (LY317615.HCl), suppresses signaling through the AKT pathway, induces apoptosis, and suppresses growth of human colon cancer and glioblastoma xenografts, Cancer Res., 2005, 65,7462-7469. DOI: 10.1158/0008-5472.CAN $\underline{-05-0071}$

22. Corvinus, F.M.; Orth, C.; Moriggl, R.; Tsareva, S.A.; Wagner, S.; Pfitzner, E.B.; Baus, D.; Kaufmann, R.; Huber, L.A.; Zatloukal, K., et al. Persistent STAT3 activation in colon cancer is associated with enhanced cell proliferation and tumor growth, Neoplasia, 2005, 7,545-555.

23. Xiong, H.; Zhang, Z.G.; Tian, X.Q.; Sun, D.F.; Liang, Q.C.; Zhang, Y.J.; Lu, R.; Chen, Y.X.; Fang, J.Y. Inhibition of JAK1, 2/STAT3 signaling induces apoptosis, cell cycle arrest, and reduces tumor cell invasion in colorectal cancer cells, Neoplasia, 2008, 10,287-297.

24. Morikawa, T.; Baba, Y.; Yamauchi, M.; Kuchiba, A.; Nosho, K.; Shima, K.; Tanaka, N.; Huttenhower, C.; Frank, D.A.; Fuchs, C.S., et al. STAT3 Expression, Molecular Features, Inflammation Patterns and Prognosis in a Database of 724 Colorectal Cancers, Clin. Cancer Res., 2011. DOI: 10.1158/10780432.CCR-10-2694
25. Goel, A.; Aggarwal, B.B. Curcumin, the golden spice from Indian saffron, is a chemosensitizer and radiosensitizer for tumors and chemoprotector and radioprotector for normal organs, Nutr. Cancer, 2010, 62,919930. DOI: 10.1080/01635581.2010.509835

26. Kusaba, T.; Nakayama, T.; Yamazumi, K.; Yakata, Y.; Yoshizaki, A.; Inoue, K.; Nagayasu, T.; Sekine, I. Activation of STAT3 is a marker of poor prognosis in human colorectal cancer, Oncol. Rep., 2006, 15,14451451.

27. Lin, Q.; Lai, R.; Chirieac, L.R.; Li, C.; Thomazy, V.A.; Grammatikakis, I.; Rassidakis, G.Z.; Zhang, W.; Fujio, Y.; Kunisada, K., et al. Constitutive activation of JAK3/STAT3 in colon carcinoma tumors and cell lines: inhibition of JAK3/STAT3 signaling induces apoptosis and cell cycle arrest of colon carcinoma cells, Am. J. Pathol., 2005, 167,969-980. DOI: 10.1016/S0002-9440(10) 61187-X

28. Klampfer, L. Signal transducers and activators of transcription (STATs): Novel targets of chemopreventive and chemotherapeutic drugs, Curr. Cancer Drug Targets, 2006, 6,107-121.

29. Lin, L.; Deangelis, S.; Foust, E.; Fuchs, J.; Li, C.; Li, P.K.; Schwartz, E.B.; Lesinski, G.B.; Benson, D.; Lu, J., et al. A novel small molecule inhibits STAT3 phosphorylation and DNA binding activity and exhibits potent growth suppressive activity in human cancer cells, Mol. Cancer, 2010, 9,217-227. DOI: $\underline{10.1186 / 1476-4598-9-217}$

30. Yakata, Y.; Nakayama, T.; Yoshizaki, A.; Kusaba, T.; Inoue, K.; Sekine, I. Expression of p-STAT3 in human gastric carcinoma: significant correlation in tumour invasion and prognosis, Int. J. Oncol., 2007, 30,437-442.

31. Labbozzetta, M.; Baruchello, R.; Marchetti, P.; Gueli, M.C.; Poma, P.; Notarbartolo, M.; Simoni, D.; D'Alessandro, N. Lack of nucleophilic addition in the isoxazole and pyrazole diketone modified analogs of curcumin; implications for their antitumor and chemosensitizing activities, Chemicobiological interactions, 2009, 181,29-36. DOI: $\underline{10.1016 / \text { j.cbi.2009.06.005 }}$ 
32. Zhao, H.; Liu, G.; Xin, Z.; Serby, M.D.; Pei, Z.; Szczepankiewicz, B.G.; Hajduk, P.J.; Abad-Zapatero, C.; Hutchins, C.W.; Lubben, T.H., et al. Isoxazole carboxylic acids as protein tyrosine phosphatase 1B (PTP1B) inhibitors, Bioorganic and Medicinal Chemistry Letters, 2004, 14,5543-5546. DOI: $\underline{10.1016 / \mathrm{j} . \mathrm{bmcl} .2004 .08 .063}$ 